Boston University School of Law Scholarly Commons at Boston University School of Law

Faculty Scholarship

6-2015

\title{
Melki in Context: Algeria and European Legal Integration
}

Daniela Caruso

Boston University School of Law

Joanna Geneve

Follow this and additional works at: https://scholarship.law.bu.edu/faculty_scholarship

Part of the European Law Commons

\section{Recommended Citation}

Daniela Caruso \& Joanna Geneve, Melki in Context: Algeria and European Legal Integration, No. 15-23 Boston University School of Law, Public Law Research Paper (2015).

Available at: https://scholarship.law.bu.edu/faculty_scholarship/69 


\section{BU School of Law}

\section{MELKI IN CONTEXT: ALGERIA AND EUROPEAN LEGAL INTEGRATION}

Cambridge University Press, forthcoming 2016

Boston University School of Law Public Law \& Legal Theory Research Paper No. 15-23

June 15, 2015

\section{Daniela Caruso}

Boston University School of Law

Joanna Geneve

Davis Polk and Wardwell LLP

This paper can be downloaded without charge at:

http://www.bu.edu/law/faculty/scholarship/workingpapers/2015.html 
Daniela Caruso $^{\square \dagger}$ and Joanna Geneve ${ }^{\square \dagger}$

MELKI IN CONTEXT: ALGERIA AND EUROPEAN LEGAL INTEGRATION

in BILL DAVIES AND FERNANDA NICOLA EDS,

EU LAW STORIES:

CONTEXTUAL AND CRITICAL HISTORIES OF EUROPEAN JURISPRUDENCE

Cambridge University Press, forthcoming 2016

\section{INTRODUCTION}

It all happened quickly in spring 2010. On Monday March 22, at 2:15 pm, three policemen on patrol duty spotted a Citroën C4 coming from Saint-Aybert - a pre-Schengen frontier post between France and Belgium - and heading south-west towards Valenciennes. ${ }^{1}$ Nothing seemed wrong with the vehicle itself or the way it was driven, but somehow its passengers - five adult males of northern African origin - caught the attention of the officers, who turned on their lights and sirens and ordered that the vehicle stop. The driver obliged and the officers proceeded to question everyone in the car. No weapons were found and there was no resistance to interrogation or physical inspection, but the contrôle revealed that two of the passengers - Aziz Melki, aged 26, and Selim Abdeli, aged 19 - had no documents authorizing their entry into France. ${ }^{2}$ Within ten minutes the two Algerians found themselves arrested, and then unwittingly at the center of a judicial saga that is now well known in EU Law circles.

The arrest of Mr. Melki and his compatriot famously triggered a preliminary reference by the Cour de Cassation to the CJEU, ${ }^{3}$ an oblique intervention by the Conseil Constitutionnel, ${ }^{4}$ a

\footnotetext{
$\square \dagger$ Professor of Law, Boston University.

$\square$ JD 2009, Harvard Law School.

${ }^{1}$ Police report, on file with authors. While remaining solely responsible for any errors, the authors thank Mr. Romain Boucq for exceptional help with sources and background information.

2 The driver and the other two passengers, all Tunisians in their 30s, had proper documents, but were briefly detained for having enabled the irregular entry into France of Melki and Abdeli, whom - allegedly - they barely knew. Id.

${ }^{3}$ Cass., Ass. Pl. QPC 16 avr. 2010, Abdeli et Melki.

${ }^{4}$ Décision No 2010-605 DC of 12 May 2010.
} 
notably conciliatory pronouncement in Luxembourg, ${ }^{5}$ and a minimalist follow-up by the Cassation. ${ }^{6}$ The case also spurred extensive reflection on a recent reform of the French legal system - the 'organic law' of 2009 whereby French courts, once deemed to be no more than 'la bouche de la loi, ${ }^{7}$ can initiate ex-post judicial review and identify possibly unconstitutional statutes. ${ }^{8}$ Many aspects of the Melki saga have been duly researched and dissected, with attention both to the primacy of EU law vis-à-vis Member States' constitutions and to the relative roles of various courts and institutions. ${ }^{9}$ The law-in-context approach of some scholars has also brought to light the power struggles of notable exponents of the French academe, judiciary, and political scene in connection to the Melki case. ${ }^{10}$ And of course the immigration law angle of the story has received due attention. ${ }^{11}$

Yet coverage of the case remains lacking in two important respects. One is the personal story of Melki and Abdeli - their particular predicament, the circumstances in which they had left their country of origin, and their current immigration status. On this front, the curious reader will remain somewhat dissatisfied, as no record exists concerning their journey before and after their arrest. All that is known is that they had remained under the authorities' radar screen until their encounter with French law enforcement, ${ }^{12}$ and that they were probably released within days. ${ }^{13}$ Sans papiers generally eschew the limelight, and the lives of Melki and Abdeli - to the best of our knowledge - have so far evaded the public eye. Nonetheless, police records and informal correspondence with Mr. Melki's attorney in Lille have allowed us to collect relevant details. Further information can be gathered by inference, on the basis of data concerning irregular migration of Algerian nationals into France as well as common policing practices in the French administrative division known as Départment du Nord (Number 59). Part II of this chapter sketches the backdrop against which the arrest and the legal representation of the two Algerians took place.

\footnotetext{
5 Aziz Melki and Sélim Abdeli, CJEU Joined Cases C-188/10 and C-189/10, 2010 E.C.R. I-5667 (hereinafter 'Melki'). See Claudina Richards, EU Law before French Courts: The Curious Incident of the Question Prioritaire de Constitutionnalité (SSRN) (describing the judgment as conciliatory).

${ }^{6}$ Cass., QPC, 29 juin 2010, Melki et Abdeli N 10-40.002.

${ }^{7}$ Montesquieu, Esprit de Lois (1777) Livre XI, Chapter 6, p. 327.

${ }^{8}$ Organic Law No 2009-1523 of 10 December 2009 on the application of Article 61-1 of the Constitution (JORF of 11 December 2009, p. 21379) inserted a new Chapter IIa, entitled 'Priority Questions on Constitutionality,' into Title II of Order No 58-1067 of 7 November 1958 on the organic law governing the Conseil constitutionnel. After this reform, ex-post judicial review by the Conseil Constitutionnel can happen upon referral from the Conseil d'Etat or from the Cour de Cassation. Lower courts must channel their questions of constitutionality through either the Cassation or the Conseil d'Etat, which operate as filters.

${ }^{9}$ Richards, supra n. 5 .

${ }^{10}$ Arthur Dyevre, The Melki Way: The Melki Case and Everything You Always Wanted to Know About French Judicial Politics (But Were Afraid to Ask), Monica Claes et al. (eds.), On Constitutional Conversations (2012).

${ }^{11}$ Steve Peers et al, EU Immigration and Asylum Law 2012, at 60-61; Damian Chalmers et al., EU Law, 2014, at 528-530.

${ }^{12}$ A search through the Fichier National des Etrangers, immediately conducted by the policemen at the time of the arrest, did not yield their names. Police Report, supra n. 1.

${ }^{13}$ Electronic correspondence with Mr. Boucq, on file with authors.
} 
The other aspect of Melki that has yet to receive proper consideration is the triangular framework in which it unfolded. Since its inception, the legal integration of Europe has had important repercussions on French-Algerian relations. Over time, the EU institutional architecture has emerged as a third vertex, besides Paris and Algiers, where old conflicts take new forms and seek new resolutions. Part III recalls some salient episodes in this story of triangulation and links the Melki narrative to larger issues - namely the Union's unresolved relation with its southern neighbors and the haunting legacy of colonial history. The difficulties encountered by Algerian sans papiers in France and the possibility of EU-level redress (the narrow subject of Melki) are only a small part of the picture. The impact of supranational law is larger and more layered when it comes to the EU's external trade and cooperation policies. With regard to Algeria, these policies began to take shape when the country - an integral part of the original EEC - gained independence from France and therefore was excised from the Community. By means of necessarily sketchy illustrations, it will be shown that these policies have often failed to ameliorate Algeria's predicaments, and at times have even hindered its economic progress. The irregular migration of Mr. Melki and many others is most often a function of Algeria's lack of economic diversification and spatial disparity - problems that remain enmeshed in the history and structure of EU-Algeria relations.

\section{AlgERIAns IN CUSTODY}

1. Representing Melki and Abdeli

Police checks of the type undergone by Aziz Melki would have been illegal on the majority of French soil, but the contrôle took place less than $20 \mathrm{~km}$ from the Belgian border. In such frontier areas, the French Code of Criminal Procedure (Article 78-2(4)) allowed random police controls for reasons of public security. In the back seat of the Citroën the two Algerians, eyes fixed on the odometer, were probably holding their breath and hoping to cover the first $20 \mathrm{~km}$ in a heartbeat. The two had entered France irregularly, i.e. without either a passport or a visa. In principle, a person in such circumstances could still receive a three-month permit of residence simply by filing an application with the local Préfecture. But in Départment 59 it seems that most irregular migrants were denied this possibility, and in any case neither Melki nor Abdeli had ever approached a Préfecture. Thus, caught with no documents at all during an ordinary inspection, the two were routinely ordered by the Préfect du Nord into administrative detention and subsequent deportation.

The plot began to thicken when the Préfect's order of March 24, requesting that detention be prolonged for another 15 days, went up for review before the Juge des Libertés in Lille. Luckily for the young Algerians, the pro bono lawyer assigned to the case was not only a business attorney, but also a Maître de Conference at the University of Lille, with experience in 
EU law and full awareness of the potential of judicial review newly introduced in the French system. For a long time, Attorney Romain Boucq had been upset by what could be characterized as ethnic profiling on the roads and by the arbitrary denial of short-term papiers in Lille. The code provision that authorized arrests in frontier zones, even though substantially upheld by the Conseil Constitutionnel in $1993,{ }^{14}$ had long struck him as contrary to France's Schengen obligations. But to make such a case within the usual constraints - i.e. to challenge a Préfect's order all the way up to the Cour de Cassation, and only then have the matter referred to the CJEU - would have taken several years of (unpaid) legal work and would have failed to provide the arrested with timely help.

On March 25, 2010, however, things suddenly looked different. The organic law introducing the question prioritaire de constitutionnalite (QPC) in the French system had entered into force earlier that month, ${ }^{15}$ providing a shortcut to EU justice. The Court de Cassation, prompted by lower courts, could now immediately ask the Conseil Constitutionnel whether Art. 78-2(4) would conflict with the rights and freedoms of Mr. Boucq's clients. On the merits, the 1993 decision of the Conseil concerning that very same provision might have been an obstacle. ${ }^{16}$ But France had since signed the Treaty of Lisbon, duly referred to in Art. 88-I of the Constitution, and perhaps a QPC could now be based on France's constitutional obligation to uphold rights and liberties conferred by EU law. Mr. Boucq outlined this strategy in oral argument, and his clever performance managed to persuade Judge Elizabeth Pierru: Melki's case was transferred to Paris immediately, with a request that the Cour de Cassation send a QPC to the Conseil Constitutionnel. ${ }^{17}$

The rest of the judicial story has already been amply discussed in legal literature, and need not be covered here at length. It may suffice to recall that on April 16 the Cour de Cassation, whose president Mr. Lamanda had previously been critical of the QPC reform, ${ }^{18}$ opted not to contact the Conseil Constitutionnel. Instead, it sent a two-pronged preliminary reference to the CJEU. One prong had to do with a possible conflict between EU law and Art. 78-2(4) of the French Code of Criminal Procedure (along the lines of Mr. Boucq's theory); the other prong questioned the EU-legality of the new organic law, positing that the procedural constraints of the QPC would interfere with French courts' obligations under TFEU Art. 267.

It is on the prong concerning the organic law that legal scholars have spent much time and ink, and for good reason. The highest French courts engaged in a veritable cross-fire, each putting forth a reading of the reform that would affirm their traditional sphere of influence. ${ }^{19}$ The CJEU, in turn, explained under which terms the organic law would remain compatible with

\footnotetext{
${ }^{14}$ Décision n ${ }^{\circ}$ 93-323 DC du 05 août 1993, Journal officiel du 7 août 1993, p. 11193

Recueil, p. 213

${ }^{15}$ On March $1^{\text {st }}, 2010$. Richards, supra n. 5.

16 Supra n. 14.

${ }^{17}$ Tribunal de Grande Instance de Lille, Juge des Libertés e de la Détention, No. 10/00422, March 25, 2010 (on file with authors).

${ }^{18}$ Lamanda Report cited in C. Richards, supra n. 5.

19 See Dyevre, supra n. 10.
} 
supranational judicial duties, and reemphasized the primacy of the preliminary reference procedure over domestic constitutional process while at the same time affirming the compatibility of the French reform with EU law. ${ }^{20}$ The result was a chorus of different voices, deemed harmonious by some and dissonant by others, but definitely loud and theatrical. ${ }^{21}$

Silenced and overshadowed by such dramatic pronouncements, the journey of Melki and Abdeli went unnoticed. Back in Lille, on March 25 the Juge des Libertés had affirmed the Préfect's order of detention only up to 15 days (i.e. through April 9). This means that long before the Cassation or the CJEU could say anything about their fate, the two Algerians had undoubtedly regained their freedom. Mr. Boucq, however, was careful not to inquire about their situation because, had he known for certain that his clients had been released, the proceedings would have lost urgency and his strategy for representation would have collapsed. When asked about them, he said - truthfully - that he had no news, and nobody - he recalls - questioned him further (Boucq 2014).

Boucq never saw his clients again. He had devoted countless hours of legal work to the case and never received more than 80 Euros per hearing (one in Lille, two in Paris, one in Luxembourg). The CJEU pronouncement made him happy: as he had predicted, the Luxembourg court found Art. 78-2(4) defective as it did not guarantee that, in practice, police controls would be any different from frontier checks. ${ }^{22}$ But Boucq would soon be disappointed. Steeped in Parisian quarrels, the Cour de Cassation was only intent on making the point that the Conseil Constitutionnel should not be consulted in this context, and that ordinary courts should remain in charge (alone or with help from Luxembourg) of reviewing French statutes' conformity with EU law. The Cassation therefore simply stated that the Juge des Libertés could decide for herself, based on the CJEU's holding, whether anything contrary to EU law had happened to Melki and Abdeli in Départment 59. ${ }^{23}$ As a result, there was no change for the many migrants in Melki's shoes other than, perhaps, a reduction in the rates of daily arrests near Lille. Most importantly, the pattern of the arrests and the attitude of the Lille Préfecture remained virtually unchanged (Boucq 2014).

Melki had nonetheless paved the way for a particular type of advocacy: invoking EU law before the Cassation to unlock the gates of immigrant detention centers. New points of leverage

\footnotetext{
${ }^{20}$ The CJEU made it clear that the QPC was not necessarily in conflict with supranational law, in so far as it would not interfere with all domestic courts' prerogative to send references to Luxembourg and to disapply, if necessary, domestic law. See esp. paras. 52-57 of the judgment. See, critically, Roberto Mastroianni, La Corte di giustizia ed il controllo di costituzionalità: Simmenthal revisited, 4 Giustizia Costituzionale 387 (2014) (noting that the CJEU, in Melki and also in $A v B$ and Others, Case C-112/13 (2014), reduced the once absolute primacy of EU law over national constitutional arrangements).

${ }^{21}$ On the musical analogy, see Richards, supra n. 5, borrowing an image used by M. Maduro in Contrapunctual Law: Europe's Constitutional Pluralism in Action.

${ }^{22}$ Para. 75 of Melki.

23““[I]l appartient au juge des libertés et de la détention d'en tirer les conséquences au regard de la régularité de la procédure dont il a été saisi.”
} 
had also emerged recently. In 2008, for example, the EU had enacted the Return Directive, ${ }^{24}$ providing detained immigrants with a number of procedural guarantees, and in 2011 two pronouncements of the CJEU - concerning, respectively, an Algerian national in Italy ${ }^{25}$ and an Armenian national in France ${ }^{26}$ - had set limits on states' discretion to criminalize illegal entry. The changes in positive law required by the CJEU were less than radical, ${ }^{27}$ but the impact of EU law was nonetheless significant, especially considering that the European Court of Human Rights had been deferential to state sovereignty on such matters. ${ }^{28}$ Based on these EU law developments, in 2012 attorney Patrice Spinosi agreed to represent the association La Cimade, assisting immigrants in custody, before the French Cassation. ${ }^{29}$ A prominent Parisian lawyer with a strong record of public representation, in 2012 Spinosi argued for a "rupture with the idea that immigrants are delinquent," 30 and the Cour listened. ${ }^{31}$ The immediate result of these judicial

pronouncements was the quick release of many illegally detained Algerians. ${ }^{32}$ The century-old practice of subjecting immigrants to criminal sanctions ${ }^{33}$ was finally receiving supranational scrutiny, and new solutions would have to be devised. Later that year Interior Minister Valls was able to implement a more systemic reform, aimed, among other things, at decoupling mere entry sans titre from penal consequences. ${ }^{34}$ The delicate political equilibrium that made such reforms possible may have found strength in the EU message that Melki and others had recently delivered in Paris.

2. The Plight of the Sans Papiers

${ }^{24}$ Directive 2008/115/EC of 16 December 2008 on common standards and procedures in Member States for returning illegally staying third-country nationals, L 348/101 (published 24 Dec. 2008).

${ }^{25}$ C-61/11 PPU, El Dridi, ECR 2011 I-03015.

${ }^{26}$ C-329/11, Alexandre Achughbabian v Préfet du Val-de-Marne, 6 Dec. 2011.

27 See, e.g., Rosa Raffaelli, Case Note: The Achubgbabian Case, Impact of the Return Directive on National Criminal Legislation, Diritto Penale Contemporaneo (2012).

${ }^{28} 22414 / 93$, Chahal v. UK 1996, § 112 (regarding the right to fair trial).

${ }^{29}$ See Pour la Cour de cassation, le séjour irrégulier ne justifie pas la garde à vue, June 6, 2012, available at http://www.liberation.fr/societe/2012/06/06/pour-la-cour-de-cassation-le-sejour-irregulier-ne-justifie-pas-la-garde-avue_824042.

${ }^{30} I \bar{d}$.

31 Avis $\mathrm{n}^{\circ} \quad 9002$ du 5 juin 2012 de la Chambre criminelle. http://www.courdecassation.fr/jurisprudence_2/chambre_criminelle_578/9002_5_23502.html. See also Cass., civ., 1ère, 5 juillet 2012, arrêt n ${ }^{\circ}$ 959, Le procureur général près la cour d'appel de Rennes c/ X., n 11-30.371.

${ }^{32}$ Serge Slama, http://combatsdroitshomme.blog.lemonde.fr/2014/08/27/pour-ses-6-ans-un-entretien-sur-cpdh-pourle-verfassungsblog/, referring to "centaines de libération de sans-papiers."

${ }^{33}$ Clifford Rosenberg, Policing Paris. The Origins of Modern immigration control between the wars (Ithaca and London, 2006), at $4-5$. Referring to the late $19^{\text {th }}$ century and to the interwar period, Rosenberg writes that "[The French police] applied methods first developed to monitor criminal populations to a group which had done nothing wrong." The criminalization of illegal entry was formalized with article L. 621-1 du Code de l'entrée et du séjour des étrangers et du droit d'asile, loi-décret du 2 mai 1938 (CESEDA).

${ }^{34}$ Loi n $^{\circ} 2012-1560$ du 31 décembre 2012. 
The circumstances of Melki's arrest - by Mr Boucq's account, the police's propensity to stop Maghrebi nationals, as well as the difficulty of obtaining titres de sojour in some Préfectures are symptoms of broader and deeper tensions between the French establishment and irregular Algerian migrants. Estimates place the number of undocumented immigrants in France at around $400,000,{ }^{35}$ with the number of Algerian sans papiers as high as $200,000 .{ }^{36}$ Algerians and others of Northern African descent are "disproportionately poor and discriminated against" in France. ${ }^{37}$ The riots of 2005 still reverberate, and France continues to be shaken by ethnically charged murders. $^{38}$

The November 28, 2012 Circular issued by the French Ministry of the Interior under Manuel Valls opened the door to the further legalization of illegal immigrants ${ }^{39}$ and explicitly encompassed Algerians, adding to the possibilities for regularization contained in the 1968 Franco-Algerian agreement and its amendments. ${ }^{40}$ However, the application of the Circular to Algerian nationals is entirely discretionary, and sans papiers like Melki continue to face a difficult struggle. Failure to obtain proper titres de sejour compromises the chances of naturalization even after many years of residence. The children of irregular migrants face high barriers as well. Simply being born in France does not confer French nationality at birth unless one parent was also born there. A child born in France to foreign parents may acquire French citizenship after age $16,{ }^{41}$ but generally only with a minimum of five years' continuous residence in France and after proof of assimilation into the French community, among other requirements. ${ }^{42}$ In the past few years, France has deported record numbers of illegal immigrants. In extreme cases, the European Court of Human Rights has found the return of Algerian nationals residing unlawfully in France to be in violation of Article 3 prohibiting torture and

\footnotetext{
35 Towards the end of 2012, Valls placed the number at approximately 350,000. See Le Parisien, 28.11.2012, Sanspapiers: Valls publie ses nouveaux critères de régularisation, http://www.leparisien.fr/politique/nouveauxcriteres-de-regularisation-pour-les-sans-papiers-28-11-2012-2362395.php.

${ }_{36}$ Algerian Taraki Club in Europe, Dec. 4. 2012, Amel Hazourli, 200.000 Algerian Illegal Immigrants Contend to Settle Their Status in France, available at http://tarakiclub.org/?p=909.

${ }^{37}$ The Economist, War by any other name, Dec. 31, 2011; Martin Evans, Algeria: France's Undeclared War 358-69 (2012). See also Miriam Ticktin, Casualties of Care: Immigration and the Politics of Humanitarianism in France (2011).

${ }^{38}$ See Scott Sayare and Steven Erlanger, Suspect in France Remains in Standoff with Police, THE NY TIMES, Mar. 21, 2012; Andrew Hussey, Algiers: A City Where France is the Promised Land - and Still the Enemy, THE GuARDIAN, Jan. 26, 2103. The Charlie Hebdo massacre was the work of two brothers of Algerian origin, and the perpetrator of the supermarket siege in eastern Paris had a history of affiliation with Algerian terrorism. See Rukmini Callimachi \& Andrew Higgins, Video Shows a Paris Gunman Declaring His Loyalty to the Islamic State, N.Y. TIMES, Jan. 11, 2015.

${ }^{39}$ Ministry of the Interior, 28.11.2012, Circular $n^{\circ}$ NOR INTK1229185C.

${ }^{40}$ Section 4.1 of the Circular extends the provisions of the Circular to Algerians, whose status is governed by a special Franco-Algerian agreement (Accord bilatéral franco algérien du 27 décembre 1968) and its amendments. Particularly important is the 2001 amendment that extended to Algerians most of the provisions of the 1998 RESEDA Act - Loi relative a l'entrée et au séjour des étrangers en France et au droit d'asile [May 11, 1998 (Loi No. 98-349)], and especially a residency permit category based on family and personal life.

${ }^{41}$ Earlier in some cases; see, e.g., French Civil Code, art. 21-11.

${ }^{42}$ See generally Maarten P. Vink \& Gerard René de Groot, Birthright Citizenship: Trends and Regulation in Europe, EUDO Citizenship Observatory, November 2010.
} 
inhuman or degrading treatment of the European Convention on Human Rights. ${ }^{43}$ In most situations, however, deportation from France finds no obstacle in supranational law.

The plight of Algerian nationals in France is further complicated by the fact that they typically do not qualify for conventional asylum, which applies only to victims of state persecution. Algerians instead tend to fall under a type of subsidiary protection, previously termed "territorial asylum," granted to refugees persecuted not by their state, but by members of civil society in their country of origin. ${ }^{44}$ Unsurprisingly, the majority of territorial asylum claimants in France are Algerian. ${ }^{45}$ French territorial asylum was granted to individuals whose life or liberty was threatened in their home countries or who were exposed to torture, inhuman or degrading treatment. ${ }^{46}$ The former Minister of the Interior Jean-Pierre Chevènement subsequently noted that this form of asylum should be applied "as an emergency humanitarian measure... of limited application...largely discretionary...for exceptional cases... and of limited significance." 47 An amendment also specified that territorial asylum should only be granted "under conditions compatible with the national interest," further expanding the scope of the French government's discretion. ${ }^{48}$ Subsidiary asylum was then communitarized. Directives 2001/95/EC and 2004/83/EC, both implemented in France, ${ }^{49}$ create minimum duties of subsidiary protection for all member states, but allow for large discretion in the 'assessment of facts and circumstances' of individual applications (Art. 4 of Directive 2004/83) and have not demonstrably altered French practices.

In sum, the particular division of powers between the EU and member states in matters of citizenship and migration flows grants France much leeway in its dealings with irregular immigration from Algeria. For some Mediterranean countries the EU has been able to conclude 'mobility partnership' agreements. ${ }^{50}$ Such deals enable regular, visa-based immigration into the EU in exchange for third countries' pledge to readmit irregular émigrés upon expulsion from Europe. No EU deal, however, has been reached with Algeria. The supranational points of leverage noted above (prohibition of border controls, Return Directive, and limits on criminalization of irregular entry or stay) remain few and are often more significant in principle than in practice. Thick EU background for Melki is to be found, therefore, not so much in EU immigration law, but rather on those aspects of EU law and policy involving Algeria's overall

\footnotetext{
${ }^{43}$ See, e.g., H.R. v. France, Application No 64780/09, judgment of 22 September 2011, final on 22 December 2011; Daoudi v. France, Application No. 19576/08.

${ }^{44}$ See Jane Freedman, Immigration and Insecurity in France 61-62 (2004).

${ }^{45} \mathrm{Id}$. at 62; Ticktin, supra n. 37, at 120 and 242 n. 24

${ }^{46}$ Loi No. 98-349 of May 11, 1998.

${ }^{47}$ National Assembly, December 15, 1997, cited from Ticktin, supra n. 37, at 146.

${ }^{48}$ Loi No. 98-349 of May 11, 1998.

${ }^{49}$ Article 1 of Act No. 2003-1176 of 10 December 2003, codified in CESEDA, supra n. 33.

${ }^{50} \mathrm{http} / / /$ ec.europa.eu/dgs/home-affairs/what-we-do/policies/international-affairs/southernmediterranean/index_en.htm.

See Michela Ceccorulli and Nicola Labanca eds., The EU, Migration and the Politics of Administrative Detention (2014).
} 
social, political, and economic performance. Whether Mr. Melki could avoid deportation thanks to clever EU lawyering is the obvious issue, but below the surface lie larger questions.

\section{Migration and Trade Asymmetries}

Algeria provides particularly salient illustrations of the EU's relations with North Africa, both because of its early participation in the European integration project and in light of presentday tensions. ${ }^{51}$ In the spirit of this edited Volume, the vicissitudes of Mr. Melki - an irregular Algerian migrant fearing deportation to his birthplace - should be seen as an opportunity to investigate the impact of EU law on the former colonies and territories of its Member States, not through broad theoretical overviews, but rather through textured accounts of meaningful legal episodes. Why is Algeria, in spite of its significant resources, still a source of massive emigration? Why is Mr. Melki's difficult journey so painfully resonant for many of his fellow nationals, fleeing Algeria's poverty and unrest? There are, of course, many possible lines of inquiry in response to these questions, but a piece of the puzzle lies - we argue - in the patterns of the EU's trade policies with its neighbors. Trade, in the context of the EU's association agreements, is touted as a tool for bettering the economic and political stability of all partners. ${ }^{52}$ Yet, the persistence of social and economic strife even among trade parties endowed with significant wealth calls into question the overall efficacy of the EU's policies and deserves, against the background of seasoned theoretical frameworks, closer investigation. ${ }^{53}$

Mercantile deals may strike readers as an elliptic object of inquiry. Since the 1960s, the emancipation of formerly colonial economies has been deemed too delicate an enterprise to be left to the simple logic of free trade, and has traditionally been framed as a matter of "development cooperation"- a rapidly evolving blend of tariff preferences, financial assistance, and now rule-of-law and democracy-building programs in favor of struggling nations. ${ }^{54}$ Yet the removal of residual barriers to trade in goods and services continues to be a core aspect of EU activity. In many circles, including the European Commission's Directorate General for Trade ("DG Trade"), trade liberalization across the Mediterranean has featured regularly as a goal and

\footnotetext{
51 The Parisian tragedies of January 2015 have brought into the spotlight all that can go wrong in post-colonial societies and called into question the efficacy of a vast array of French, European, and more broadly "Western" choices in the Mediterranean region.

52 See, critically, VISHAAL KISHORE, RICARDO'S GAUNTLET:. ECONOMIC FICTION AND THE FLAWED CASE FOR FREE TRADE (2014).

${ }^{53}$ See e.g. Vassilis Monastiriotis, Dimitris Kallioras \& George Petrakos, The Regional Impact of EU Association Agreements: Lessons for the ENP from the CEE Experience 20 (LEQS Discussion Paper Series, Discussion Paper No. 80/2014, 2014). On the questionable effects of the EU's trade liberalization in Morocco and Tunisia, see Mark Langan, Normative Power Europe in the Maghreb: A Moral Economy Perspective on the Deep and Comprehensive Free Trade Agreements (August 15, 2014), available at SSRN: http://ssrn.com/abstract=2487106. To this day foundational for such empirical inquiries is the theoretical framework of Johan Galtung, The Lomé Convention and Neo-Capitalism, 6 African Review 33 (1976).

54 PIET EECKHOUT, EU EXTERNAL RELATIONS, 451 (2nd ed. OUP 2011), p. 451 ff.; Lorand Bartels, The Trade and Development Policy of the European Union, 18 EUR. J. INT'L L. 715 (2007).
} 
is often an established reality. The association agreements linking the EU with North African states all aim at reciprocal market opening as a matter of principle. In an era of generally low trade barriers, such arrangements may seem unremarkable, but they produce, as we shall see, important and at times troubling distributive effects.

The following pages explore some of the legal arrangements that govern the economic interaction between the EU and Algeria, with particular regard to their onset at the start of the integration project. The goal is to situate Mr. Melki's difficult journey within a broader and older EU law story.

\section{The EU's Work On AlgERIA’s PREDICAMENTS: COOPERATION AND TRADE}

\section{Algeria's Economy Today: An Overview}

The huge risks and sacrifices that so many Algerian migrants face in Europe give us a sense of the misery they leave behind when they embark on their journey of hope. High rates of unemployment, combined with lack of faith in the ruling class, generate massive emigration fluxes. ${ }^{55}$ The nature of misery in contemporary Algeria is, however, not obvious. There is a significant discrepancy between the image of a destitute land which migrants eagerly flee and the relatively solid portrait of Algeria that emerges from aggregate data. Algeria is a 'middleincome' country that has managed, since 2005, to refrain from external borrowing. The extra revenue due to high energy prices in the early 2000s allowed the Algerian government to repay its foreign debt and increase its geopolitical importance. According to a recent economic profile,

Algeria has the 10th-largest reserves of natural gas in the world and is the sixth-largest gas exporter. It ranks 16th in oil reserves. Strong revenues from hydrocarbon exports have brought Algeria relative macroeconomic stability, with foreign currency reserves approaching \$200 billion and a large budget stabilization fund available for tapping. In addition, Algeria's external debt is extremely low at about $2 \%$ of GDP. ${ }^{56}$

Moreover, the country was notably not shaken by the Arab Spring and has been relatively stable for the past 10 years. ${ }^{57}$ Terrorist attacks, mostly launched from neighboring countries'

\footnotetext{
${ }^{55}$ See David N. Margolis, Egidio Luis Miotti, El Mouhoub Mouhoud and Joel Oudinet, To Have and Have Not: Migration, Remittances, Poverty and Inequality in Algeria, IZA Discussion Paper No. 7747 (Nov. 2013); Vivienne Walt, With Limited Freedoms, Many Algerians Vote with Their Feet, TIMES MAGAZINE, Feb. 18, 2013.

${ }^{56}$ Index Mundi, Algeria Economy Profile 2013, http://www.indexmundi.com/algeria/economy_profile.html.

${ }^{57}$ On the Algerian violence of the 1990s, see LUIS MARTINEZ \& JOHN ENTELIS, THE ALGERIAN CIVIL WAR (2000); see also Eleanor Beardsley, Algeria's Black Decade Still Weighs Heavily, NPR, Apr. 25, 2011.
} 
Islamic extremists, periodically wreak havoc and slow down the pace of foreign investment, ${ }^{58}$ but they remain relatively self-contained and do not derail the country's productive life.

The point is that the wealth generated by hydrocarbons comes with two significant drawbacks: first, it is concentrated in the hands of the country's elite or siphoned off to foreign investors, with no immediate benefits for the Algerian poor; ${ }^{59}$ second, it is excessively dependent on world price fluctuation and is therefore subject to sudden contractions. The country's economy continues to be plagued by lack of diversification (with hydrocarbons accounting for 95\% of Algerian export earnings) and spatial disparity, i.e. abysmal poverty in rural areas and largely disappointing performance of privately owned business. Virtually all sectors of Algeria's economy, with the exception of oil and gas, still struggle.

The cause of such problems lies, from the perspective of developed countries, in the Algerian government's reluctance to liberalize. Algeria's patterns of state intervention in the economy, expansive fiscal policy, and relatively profligate public spending stand in stark contrast with current recipes for progress. ${ }^{60}$ The World Bank's "Doing Business" report of 2013 ranks Algeria $152^{\text {nd }}$ out of 185 economies, indicating that the Algerian regulatory environment is not hospitable to business, and in particular to small and medium enterprises. ${ }^{61}$

It is indeed common knowledge that the Algerian government keeps a tight grip on economic activity. President Boumedienne's large project of nationalization in 1971 has since given way to a more liberal attitude towards private entrepreneurship, but a cautious and cagey attitude towards foreign investment continues to characterize government policies. The Hydrocarbons Law of 2005 was meant to terminate Sonatrach's monopoly over all hydrocarbonrelated activities, from exploration to transportation, and indeed paved the way for new and transparent bidding processes for international investors. A governmental order of 2006, however, guaranteed a $51 \%$ Sonatrach share in all ventures, and introduced additional tax burdens for foreign investors. ${ }^{62}$

This concentration of power in governmental hands is also said to operate as an obstacle to Algeria's own private entrepreneurship. The African Development Bank has noted the Algerian government's insistence on pouring resources into state-owned industries. ${ }^{63}$ This policy

\footnotetext{
${ }^{58}$ Algeria's oil and gas. Not so jolly, THE ECONOMIST, Feb. 9, 2013.

${ }^{59}$ See Lama Abu-Odeh, On Law and the Transition to Market: The Case of Egypt, 23 Emory Int'1 L. Rev. 351 (2009) (discussing the interplay of market dynamics and rentier state politics in oil-rich economies).

${ }^{60}$ See The World Bank, Algeria Overview, http://www.worldbank.org/en/country/algeria/overview (last updated Mar. 12, 2014).

61 The World Bank, Doing Business 2014, Economy Profile: Algeria, http://www.doingbusiness.org/ /media/giawb/doing\%20business/documents/profiles/country/DZA.pdf.

${ }^{62}$ See Omar T. Mohammedi, International Trade and Investment in Algeria: An Overview, 18 Mich. ST. J. INT'L L. 375, 386 (2010) (quoting Jean-Michel Meyer, Investissement: l'Algérie impose sa loi, JEUNE AFrIQUE, July 28, 2009).

${ }^{63}$ African Development Bank Group, People's Democratic Republic of Algeria: Dialogue Note 2011-2012, 2.4.9 (2011).
} 
is radically at odds with Europe's liberalization mantra, both within the energy sector and across the board of economic activities. ${ }^{64}$ To be sure, there are occasional nods to the fact that Algeria's timely reduction of foreign debt sheltered the country from the global financial turmoil of $2008,{ }^{65}$ but more common is a general condemnation of Algeria's economic policies, both towards Foreign Direct Investment (FDI) and with regard to domestic enterprises. ${ }^{66}$

Against this background, has the EU truly contributed to the betterment of the country to diversifying its economy, to restructuring its productive sectors, or to raising the standards of its rural life? The answer to this question is mixed. As observed, it is common, in Europe and elsewhere, to blame Algeria for its own troubles, but there is room for considering whether EU policies may have, over time, also tied Algeria to the status quo. The following sections set the Melki story in the larger context of EU-Algeria relations and make the point that the EU, while aiming to alleviate the misery that prompts irregular migration, has at times compounded endogenous Algerian problems.

\section{Cooperation}

Ameliorating the economic conditions of the Maghreb, and of Algeria in particular, is a goal dear to the EU polity for reasons that include energy security, the fight against terrorism, humanitarian concerns, and immigration control. The Algerian government is a desirable bulwark against terrorism and irregular migration from the heart of Africa. Europe is thus invested in shoring up its strength and enabling its 'prosperity and stability.' The onset of a policy of 'cooperation' with Algeria was marked by the Cooperation Agreement of 1976 - one in a series of treaties negotiated by the EEC with North-African countries. Cooperation evolved in a network of Euro-Mediterranean deals, ${ }^{67}$ in turn shaped by the broad goals of the European Neighborhood Policy (ENP) ${ }^{68}$ and most recently equipped with an agile operative instrument (ENI). ${ }^{69}$

\footnotetext{
${ }^{64}$ Statement by IMF Managing Director Christine Lagarde at the Conclusion of her Visit to Algeria, Press Release No. 13/72, Mar. 13, 2013 (pleading for "a new awakening of the private sector" and "[s]tructural reforms to enhance the business climate[.]").

${ }^{65}$ See, e.g., African Development Bank Group, supra n. 63.

${ }^{66}$ See, e.g., Telecoms in Algeria: A Lost Generation, ThE ECONOMIST, Oct. 26, 2013.

${ }^{67}$ See, e.g., European Commission Press Release, IP/13/753, July 30, 2013, http://europa.eu/rapid/press-release_IP13-753_en.htm (outlining the "SPRING" programme - Support for Partnership, Reform and Inclusive Growth - to support "economic and political governance in Algeria").

${ }^{68}$ The ENP was established in 2003 with the goal of spreading prosperity and stability in the EU's post-enlargement neighborhood. It was then differentiated into the Union for the Mediterranean (also known as the 2008 "Barcelona Process") and the Eastern Partnership (2009). See Richard G. Whitman and Stefan Wolff, Much Ado about Nothing? The European Neighborhood Policy in Context, in The European NeIGHBorhood Policy in Perspective: CONTEXT, IMPLEMENTATION AND IMPACT 3 (Richard G. Whitman \& Stefan Wolff eds., 2010).

${ }^{69}$ REGULATION (EU) No 232/2014 OF THE EUROPEAN PARLIAMENT AND OF THE COUNCIL of 11 March 2014 establishing a European Neighbourhood Instrument (ENI).
} 
Cooperation is meant as an alternative to the harshness of free trade with developing countries and aims to pursue a series of classical development goals: ${ }^{70}$ promotion of the rule of law, access to justice and institutional capacity, fight against corruption, environmental management, sustainable development, job creation, promotion of human rights, democracy, and gender equality. Toward such goals, the EU promises to lend know-how, institutional expertise and, of course, money. ${ }^{71}$ Help, however, comes with strings and is conditioned upon the partner state's willingness to engage in meaningful structural reforms: reducing the scope of monopolies, protecting intellectual property, cutting red tape, and letting the private sector - whether local or foreign - take charge of yet untapped resources. ${ }^{72}$

The difficulties have been remarkable. According to the 2002 Association Agreement, which replaced and upgraded the 1976 Cooperation Agreement, the full-range implementation and funding of cooperation initiatives required an Action Plan, supposed to describe in detail Algeria's commitments to reform and the EU's necessary supporting measures. Yet, as of March 2015, no Action Plan has seen the light of day. ${ }^{73}$ Conditionality has worked well with Algeria's more palatable and reform-oriented neighbors - most notably Morocco - but not so with Algeria itself. $^{74}$ Due to its statist tendencies, the Algerian government comes across as the "most awkward" partner 75 of the EU amongst North-African states. Most recently, the Commission has sketched for the Council a proposed Framework Agreement that would allow Algeria to participate in Union programmes and receive significant assistance, ${ }^{76}$ but Algeria seems to be

70 See, e.g., Fawaz Yusuf, A Structural Change Analysis of EU-Moroccan Trade Liberalisation and Economic Development Between 1995 and 2010, 19 J. N. AFR. STUD. 413 (2014) (questioning, with specific regard to the Maghreb region, the EU's ability to generate any real economic diversification and enhanced employment opportunities by means of free trade).

${ }^{71}$ European Commission Memo, ENP Package - Algeria, March 27, 2014. http://europa.eu/rapid/press-release_MEMO-14-219_en.htm.

${ }^{72}$ Euro-Mediterranean Agreement establishing an Association between the European Community and its Member States, of the one part, and the People's Democratic Republic of Algeria, of the other part, 2005 OJ L 265/2 (signed 22 April 2002; entry into force 1 September 2005) (hereinafter "EU-Algeria Association Agreement), especially Art. 32,39 and 44.

73 European Commission, External Action Service, SWD (2015) 77 final (Mar. 25, 2015) Implementation of the European Neighbourhood Policy Statistics, http://eeas.europa.eu/enp/pdf/2015/enp-statistics-report-2014_en.pdf (docuemnting delays in bilateral cooperation).

74 See Nick Whitney and Anthony Dworkin, A Power Audit of EU-North Africa Relations, European Council of Foreign Relations (ECFR), 44 (2012), http://www.ecfr.eu/page/-/ECFR62_NAPA_REPORT.pdf.

${ }^{75}$ See Federica Bicchi, The Impact of the ENP on EU-North Africa Relations: The Good, the Bad and the Ugly, in Whitman \& Wolff, supra n. 64, at 206, 218; Hakim Darbouche, Energising EU-Algerian Relations, 1 MAGHREB CENTER J. 1 (2010). For a general critique of the ENP, see Nathalie Tocci, The Neighbourhood Policy is Dead. What's Next for European Foreign Policy Along its Arc of Instability?, IAI 2014.

76 Proposal for a COUNCIL DECISION on the conclusion of the Protocol to the Euro-Mediterranean Agreement establishing an association between the European Communities and their Member States, of the one part, and the Republic of Algeria, of the other part, on a Framework Agreement between the European Union and the Republic of Algeria on the general principles for the participation of the Republic of Algeria in Union programmes, COM/2014/0384 final - 2014/0195 (NLE). 
politically "frozen." 77 Thus, the distribution of EU aid in the ENP context sees Algeria at the bottom of the list of recipients. ${ }^{78}$ The following critique, directed to the ENP overall, captures particularly well the cooperation impasse between the EU and Algeria:

$[R]$ ather than offering a clear carrot from the outset, under the ENP the EU requires countries to undertake a variety of reforms, and only once reforms have been implemented will the EU consider offering the possibility of some form of deeper relations. $^{79}$

The carrot and stick game known as conditionality seems to have turned into a chicken and egg problem: Algeria and the EU cannot agree on whether structural reform depends on aid or vice versa. The result is gridlock: the EU places even more emphasis on conditionality ("more for more") and Algeria remains unyielding.

\section{Reluctance revisited}

Overall, the EU seems poised to pressure Algeria into opening its markets to competition. For Algeria, however, the fluctuation of prices and the decreased predictability that come from market liberalization are harbingers of serious challenges. A loss of market share is a terrifying prospect for a country whose eggs are in one basket, and Algeria's economy remains entirely dependent on its hydrocarbon reserves. The reasons for this predicament are not exclusively endogenous. The EU-Algeria 2013 Memorandum of Understanding on strategic energy partnership, for instance, further consolidates the narrow range of Algeria's productive activities (oil and gas). ${ }^{80}$ The Memorandum does mention the possibility of cooperation in renewable energy sectors, but a recent attempt to boost solar energy production in Algeria has not proven viable as a result of shrinking budgets in EU member states, and it is by no means clear that this Memorandum could resurrect the solar energy project. ${ }^{81}$ Algeria's mistrust, against this background, does not seem irrational.

There are, as well, other explanations for Algeria's seemingly obstinate and self-defeating posture in the face of EU offers. A closer look at the details of the agreements that have been negotiated reveals another side of the EU-Algeria relations - namely, trade in goods - which

\footnotetext{
77 Erwan Lannon, Entry into Force of the New European Neighbourhood Policy and Negotiation of "Deep and Comprehensive" Free Trade Areas: A European Neighbourhood Policy Running at Different Speeds, IEMED Mediterranean Yearbook 2014, 228.

78 See generally Vicky Reynaert, Explaining EU Aid Allocation in the Mediterranean: A Fuzzy-Set Qualitative Comparative Analysis, 16 MEDIT. POL. 405 (2011).

${ }^{79}$ Whitman \& Wolff, supra n. 68 , at 14.

${ }^{80}$ European Commission Press Release, President Barroso visits Algeria and signs a memorandum on energy, July 7, 2013, http://ec.europa.eu/commission_2010-2014/president/news/archives/2013/07/20130707_1_en.htm.

81 The "Desertec Industrial Initiative" project, which held much promise in 2005, envisaged large exports to Europe of solar energy gathered in Algerian deserted areas, with heavy European investment in solar technology. Desertec abandons Sahara solar power export dream, Euractiv, May 31, 2013.
} 
receives less attention than cooperation, and yet is particularly revealing of endemic and historically charged imbalances of power. There is, in the EU's proffered trade deals, a growing insistence on parity of trade terms that is at odds with the rhetoric of cooperation and instead cast in a neoliberal frame. The website of the Commission's DG Trade informs the public that, as of 2014, Algeria no longer benefits from the EU's Generalized System of Preferences (GSP), because its Free Trade Agreement (FTA) with the EU is finally coming to fruition. ${ }^{82}$ For countries like Algeria, whose citizens still hold vivid memories of colonial times, the ongoing transition from differential regimes to fully reciprocal FTAs could represent modernity and emancipation. There is much energy and dignity in such developments, and the tone of the DG Trade's announcement is accordingly upbeat. ${ }^{83}$ EU trade policies vis-à-vis Algeria, however, have a less than stellar record in terms of effectiveness, and are worth exploring in some detail towards the goal of understanding why the relation between the EU and Algeria, half a century after the Evian Accords, retains structural dependence features.

\section{Wine and the Origin of EEC-Algeria Trade}

The bloodiest time in French-Algerian history - the Algerian war of independence coincided with Algeria's entry into the EEC, not as a member state but as an integral part of France. ${ }^{84}$ European inclusion was short-lived: as a result of the Evian Accords of 1962, Algeria was excised from the Community, and many Algerian-born persons, having enjoyed French nationality, returned to third-country national status. ${ }^{85}$ The same happened to goods. Algerian wine, for instance, initially treated as French for custom purposes, suddenly became a thirdcountry product. This story illustrates the possibly negative externalities of EU market integration and casts EU policies towards Algeria in a less than glowing light.

The wine industry had been born on Algerian soil in the 1870 s, following an epidemic of phylloxera in France. Vine farmers had relocated en masse in Algeria, carrying with them sophisticated wine-making technologies - most importantly refrigeration systems - and taking advantage of native farmers as cheap labor. Imports from Algeria ensured adequate wine supply in France in times of scarcity, but even when production resumed abundant inside the Hexagon, the Pieds Noirs kept a steady market share in France. By the 1950s Algeria had become the

82 European Commission, Directorate General for Trade, Countries and Regions: Algeria, http://ec.europa.eu/trade/policy/countries-and-regions/countries/algeria/ (last visited December 15, 2014).

83 Theoretical underpinnings for the EU's liberal trade aspirations were articulated by, among others, Béla A. Balassa, The Importance of Trade for Developing Countries, in NEW DIRECTIONS IN THE WORLD ECONOMY 3 (Béla A. Balassa ed., 1989).

${ }^{84}$ Kalypso Nicolaïdis, Southern Barbarians? A post-colonial critique of EUniversalism, in ECHOES OF EMPIRE: MEMORY, IDENTITY AND COLONIAL LEGACIES 247 (Kalypso Nicolaïdis, Berny Sèbe \& Gabrielle Maas eds., 2014).

85 One such person was Mr. Belbouab, whose German pension was endangered by this de jure loss of French nationality. Case 10/78 Belbouab v Bundesknappschaft [1978] ECR 1915. 
largest exporter of wine in the world. ${ }^{86}$ For religious and political reasons, there was no consumption of wine amongst Algerians, and France was its only market. ${ }^{87}$

The nationalization of Algerian agriculture, declared immediately after independence, led wine producers of French nationality to return home, leaving behind a thriving industry. Algeria relied for a while on a 1964 French commitment to purchase its wine - part of a larger cooperation effort in the aftermath of independence - but France, upon Italy's insistence, did not honor that deal. ${ }^{88}$ The Algerian government also sought to maintain, at least de facto, a privileged trade regime with the Community and refused to sign a 1969 cooperation agreement that would hurt its ability to export agricultural products to the EEC. ${ }^{89}$ But things were inexorably changing.

As soon as France lost its ability to erect protectionist barriers against other European wines, imports from Algeria lost their competitive edge. ${ }^{90}$ An EEC Regulation designed to launch a Common Wine Policy also determined that bottles produced on the Continent could not contain wine of non-EEC origin. ${ }^{91}$ The onset of European integration resulted in the complete demise of a once profitable stream of commerce.

This episode, by now well documented, is a dramatic illustration of the trade diverting effects of market integration in the EU. It is often the case that the enablement of free trade within a given region of the world upsets preexisting patterns of commerce in third countries. However, Algeria was no third country when European integration began, and counted on trade continuity after political independence. As time went on, it became increasingly clear that Algeria could no longer rely on privileged commercial ties to Paris, due to the Métropole's new allegiances and obligations towards the Community's Member States. In 1978, when the Cooperation Agreement entered into force, Algeria's economy suffered additional setbacks. With regard to goods, the Cooperation Agreement offered Algeria free access to the EEC market for most of its non-agricultural products, as well as some tariff concessions for its agricultural exports. At the same time, textiles and refined petroleum products from Algeria stopped benefiting from zero rate tariffs. Seasonal restrictions were also imposed upon the import of agricultural products, with "disastrous" consequences for Algerian exports. ${ }^{92}$ The 1980s'

\footnotetext{
${ }^{86}$ Giulia Meloni and Johan Swinnen, The Rise and Fall of the World's Largest Wine Exporter (and its Institutional Legacy), American Association of Wine Economists Working Paper No. 134 (Feb. 2013), http://www.wineeconomics.org/aawe/wp-content/uploads/2013/02/AAWE_WP134.pdf.

${ }^{87} I d$.

${ }^{88}$ Muriam Haleh Davis, Eurafrica and De Gaulle's Constantine Plan - Algeria and the European Communities 1958-1962, European University Institute, July 30, 2013, http://www.eui.eu/Research/HistoricalArchivesOfEU/News/2013/07-30-

EurafricaandDeGaullesConstantinePlan.aspx.

${ }^{89}$ Issam Nedjiah, Les relations euro-algériennes de la coopération au partenariat, 10 DOMITIA 149, 150-51 (2008).

${ }^{90}$ Davis, supra n. 88.

${ }^{91}$ Council Regulation 816/70, art. 26, 1970 OJ L 99/1 (EC). See Jeffrey A. Munsie, A Brief History of the International Regulation of Wine Production (2002).

92 See European Institute for Research on Mediterranean and Euro-Arab Cooperation (MEDEA), EU-Algeria Relations, http://www.medea.be/en/countries/algeria/eu-algeria-relations/ (last visited on December 15, 2014).
} 
accession of Greece, Spain, and Portugal dealt an additional blow to Algeria's chance of selling its agricultural goods competitively to EEC customers. ${ }^{93}$

\section{Trade in goods today}

The free trade agreement referred to by the Commission in the aforementioned web announcement is a section of the 2002 Association Agreement, which laid the groundwork for the effacement of tariffs in EU-Algeria commerce. ${ }^{94}$ Following the blueprint of the EU's GSP, the Agreement provided for immediate non-reciprocal concessions: as soon as the Agreement became effective in 2005, the EU dropped the tariffs down to zero on most Algerian imports. ${ }^{95}$ Algeria, by contrast, was allowed to keep in place temporary custom duties to protect national industries and was given 12 years to phase them out. This lopsided arrangement, gracious enough to require Algeria to open up to Europe with regard to services and foreign investment, was favorable to Algeria only in form. In substance, for several reasons, it was unlikely to stimulate imports. First, the EU grants free-trade privileges to an increasingly large number of countries, ${ }^{96}$ and duty-free access to its market is now the baseline for most competitors certainly not a coveted prize for the few. Second, some exporting countries have negotiated better terms (i.e. duty-free access for a broader range of products) than Algeria could ever receive, because Algeria does not qualify as a 'vulnerable' economy by EU standards. ${ }^{97}$ Third, and most importantly, duty-free access only benefits those industries whose goods would be competitive in terms of both quality and price in the absence of trade barriers. Many of Algeria's products, however, are less than competitive, and are not likely to win the hearts and purses of EU consumers even if unencumbered by tariffs. As a result, the asymmetric trade concessions granted by the EU have been less helpful than anticipated.

The detailed data on EU-Algeria trade released by the Commission corroborate this sobering assessment. ${ }^{98}$ Statistical figures track the trend of imports and exports from 2008 to 2012 - well after the entry into force of the Association Agreement - and illustrate very clearly that the EU market is notably not flooded with any of the goods that either farmers or small and medium enterprises in Algeria are likely to produce. Empirical studies show that Algerian exports to the EU in all non-hydrocarbon sectors have not experienced any significant trade

\footnotetext{
93 It appears that Algerian food exports, including cereal, had doubled in between 1976 and 1986 , but then contracted again. See id.

${ }^{94}$ EU-Algeria Association Agreement, supra n. 72, Title I.

95 See id. art. 9.

${ }^{96}$ Within the Southern Mediterranean Region, the EU is currently negotiating several Deep and Comprehensive Free Trade Agreements (DCFTA).

${ }^{97}$ Algeria does not meet the vulnerability criteria that let other countries receive more favorable treatment (GSP+). Regulation (EU) No 978/2012 of the European Parliament and of the Council establishes eligibility criteria for special incentive arrangement for sustainable development and good governance (GSP+). 2012 OJ L 303/1.

98 European Commission, DG Trade, Algeria: EU Bilateral Trade and Trade with the World, July 5 , 2013 (hereinafter "DG Trade: Algeria").
} 
creation. ${ }^{99}$ Imports into the EU from Algeria have grown significantly in the aggregate, but this growth is only due to a spike in imports of "mineral products." 100 Trade in minerals, given the structure and ownership of Algerian natural resources, brings revenue either to the government or - since the partial liberalization of the sector ${ }^{101}$ - to foreign investment, but not to middlescale entrepreneurship. With the exception of animal hides and leather, Algeria is a net importer of all manufactured items, agricultural products, and textiles. Algerian textiles, in particular, are no longer to be found in the list of exports to the EU. ${ }^{102}$ Textiles are an important part of Algeria's traditional economy and also a staple of small and medium enterprises, but the textile sector finds no reward in the EU market. ${ }^{103}$

In parallel, the ongoing dismantlement of Algerian custom duties has resulted in a significant boost to EU exports, which reduce the consumption of domestic goods, and in a loss of custom revenues for the state. For these reasons, in 2012 the Algerian government was given a longer time to implement the total phase-out, now postponed until 2020. ${ }^{104}$ In sum, the duty-free access to the EU market has not managed to alter the export patterns of Algeria. The EU's trade policy is not (yet) conducive to Algeria's market diversification, and therefore does not leverage goods markets as tools to relieve Algeria's socio-economic disparity.

\section{CONCLUSION}

This Chapter has aimed to place Melki in its broader context. It has first outlined Mr. Melki's irregular entry into France and the clever representation strategy devised by his counsel on the basis of EU law. Next, it has explored the plight of many Algerian sans papiers living in France and observed the (feeble) impact of EU law on their immediate predicaments. It has then broadened the inquiry to encompass multiple levels of EU-based intervention on the social, economic and political reality of Algeria, starting with cooperation measures within the European Neighborhood Policy and continuing with trade policies in the goods sector. It has then

\footnotetext{
99 See Mohamed Y. Haddoud, Keith Salmon, Paul Jones \& Robert Newbery, The Impact of Regional Trade Agreements on North African Countries' Foreign Trade and Economic Welfare, Evidence from Algeria and the European Union Association Agreement, www.regionalstudies.org/uploads/HADDOUD_RSA_FINAL_COPY.pdf ("[T]rade creation occurred mainly in imports rather than exports ... . [A]lthough the regional membership may create trade for North African countries, it may not be sufficient to overcome export issues[.]")

100 The value of imports of mineral products went from 20,080 million Euros in 2008 to 31,968 million Euros in 2012. DG Trade: Algeria, supra n. 98.

${ }^{101}$ Encyclopedia of the Nations, Algeria, http://www.nationsencyclopedia.com/economies/Africa/Algeria.html (last visited Aug. 24, 2014) (hereinafter "Encyclopedia").

102 The value of Algerian textiles exported to the EU, expressed in millions of Euros, was 1 in 2008-2009 and has been 0 since 2012. DG Trade: Algeria, supra n. 98.

${ }^{103}$ Encyclopedia, supra n. 101.

${ }^{104}$ Ulrika Lomas, Algeria delays implementation of FTA with EU, TAXNEWS, Sept. 4, 2012 (reporting that, according to Algerian trade minister Mustapha Benbada, "the existing association agreement with the EU cost Algeria USD2.5m in lost customs duties between 2005 and 2009, while investments from the EU have not been as strong as initially anticipated. At the same time, Algerian imports from the EU have increased dramatically.")
} 
sketched one particular episode - the collapse of Algerian wine trade - that illustrates both the long-term damage of colonialism and the possible negative effects of European integration on its neighborhood. In several cases, the opening of markets has not worked towards diversification, but rather against it. Wine in the 1960s, textiles in the 1980s, and most recently clean energy initiatives have provided illustrations of a recurrent pattern - one in which both local initiative and foreign investment fail to prompt diversification and rather ossify entrenched economic structures. ${ }^{105}$ Recalling Johan Galtung's analysis, we might still discern here a "bridgehead which the center of the Center nation establishes with the center of the Periphery nation," leaving behind the latter's rural and urban poor. ${ }^{106}$ Both the political economy of Algeria and its deals with the EU have significantly evolved over time, but the earlier setbacks of trade diversion cast long shadows on the cooperation policies implemented by the EU in recent years. The journey of Mr. Melki connects Algeria, physically and metaphorically, with the EU - a regional entity that struggles to set aside colonial history, ${ }^{107}$ and yet at times rewrites it.

\footnotetext{
${ }^{105}$ Langan, supra n. 53.

${ }^{106}$ Johan Galtung, A Structural Theory of Imperialism, Oslo 1971.

${ }^{107}$ Nicolaïdis, supra n. 84.
} 